UDC 811.111:378.018.43:34

\title{
Current state and perspectives of distance learning of the English language during professional training of future economists of the National University of Food Technologies
}

\author{
Harkusha 0. ${ }^{*}$ \\ National University of Food Technologies, Kyiv, Ukraine
}

Received: $10.03 .2019 \quad$ Accepted: 20.03 .2019

\begin{abstract}
The article is devoted to the consideration of the current state and perspectives of the development of a distance learning system in Ukraine in general, and at the National University of Food Technologies, as one of the powerful educational and scientific complexes of the state, which is also known abroad, in particular. The leading state and foreign scientists and scholars who have been studying various aspects of distance learning and have made a significant contribution to the development of pedagogical science are listed. The results of foreign meetings are described; the arguments for the establishment and development of distance education in the world are given. The advantages and disadvantages of online education are described; the features of this type of training are listed. In order to better understanding of the concept of distance education system, one of the key points of the article, in our opinion, is to characterize the differences between distance education and extramural education. The article discusses the concept of distance learning as such in result of which the student receives a state diploma of higher education. The study was narrowed down to a separate category of students who undergo educational and professional training in economic specialties on a distance basis. One of the mandatory subjects in NUPT is a foreign language, the study of which is of particular importance for the future development and competitiveness of both an individual student and the state as a whole. The objectives of the study of the foreign language by future economists are to develop the skills in mastering highly specialized vocabulary and terms, conducting business conversations and correspondence with foreign partners. To achieve this goal with the help of distance education, it is necessary to develop special theoretical and practical courses that would give the opportunity to study the subject in full, master and develop the skills of oral and written business speech. The article discusses a phased transition and the introduction of a distance education system in NUFTs. The prerequisites for the development of distance education and ways of further development are indicated. It is noted that the main means of distance education in NUFT is the Moodle system. The article describes the advantages and disadvantages of using this system, the ways of its improvement and modernization are noted. In the section "Discussion" for comparison of the obtained results of the research some achievements of other higher educational institutions of Ukraine are submitted for consideration.

Key words: distance learning, distance technologies, the English language, professional training, economists, higher education
\end{abstract}

\section{Стан та перспективи дистанційного навчання іноземній мові в процесі підготовки майбутніх економістів Національного університету харчових технологій}

\author{
Гаркуша 0. 0. \\ Національний університет харчових технологій, Київ, Україна
}

\begin{abstract}
Анотація. Стаптя присвячена розгляду поточного стану та перспектив розвитку системи дистанційного навчання в Україні взагалі, та в Національному університеті харчових технологій, як одного з потужних навчально-наукових комплексів держави, яке відоме й за ї̈ межами, зокрема. Перелічуються провідні державні та іноземні науковці та освітяни, які займалися вивченням різних аспектів дистанційного навчання та зробили значний внесок в розвиток педагогічної науки. Описуються результати закордонних зустрічей, наводяться аргументи щодо впровадження та розвитку дистанційної освіти в світі. Детально характеризуються переваги та недоліки онлайн освіти, перелічуються особливості даного виду навчання. 3
\end{abstract}

Corresponding Author:

Відповідальний aвтор:
Harkusha Olena Oleksandrivna. Tel. 0953124374. E-mail: elena.garkusha1990@gmail.com National University of Food Technologies, Volodymyrska str. 68, Kyiv, Ukraine, 01601.

Гаркуша Олена Олександрівна. Тел. 0953124374. E-mail: elena.garkusha1990@gmail.com Національний університет харчових технологій, вул. Володимирська, 68, м. Київ, Україна, 01601. 
метою кращого розуміння поняття системи дистанційної освіти, одним з ключових моментів статті, на нашу думку, є характеристика відмінностей дистанційної форми освіти від заочної. В статті розглядається поняття дистанційного навчання як таке по закінченню котрого студент отримує диплом державного зразка про вищу освіту. Дослідження було звужене до окремої категорії студентів, які проходять навчально-професійну підготовку за спеціальностями економічного профілю на дистанційній основі. Однією з обов'язкових дисциплін в НУХТ $€$ іноземна мова, вивчення якої набуває особливого значення для майбутнього розвитку та конкурентоспроможності як окремого студента так і держави в цілому. Цілями вивчення дисципліни іноземна мова студентів-економістів $€$ розвиток навичок оперування вузькоспеціалізованою лексикою та термінами, ведення ділової бесіди та переписки з іноземними партнерами. Для досягнення поставленої мети на рівні дистанційної освіти, необхідним є розробка спеціальних теоретичних та практичних курсів які б давали можливість вивчати дисципліну в повному обсязі, оволодіти та розвити навички усного й писемного ділового мовлення. В статті розглядається поетапний перехід та впровадження системи дистанційної освіти в НУXT. Зазначаються передумови становлення дистанційної освіти та шляхи її подальшого розвитку. Відмічається, що основним засобом дистанційної освіти в НУХТ є система Moodle. В статті описуються переваги та недоліки використання даної системи, відмічаються шляхи її вдосконалення та модернізації. В секції «Обговорення» для порівняння набутих результатів дослідження подаються для розгляду окремі здобутки інших вищих навчальних закладів України.

Ключові слова: дистанційне навчання, дистанційні технології, англійська мова, професійна підготовка, економісти, вища освіта

\title{
Состояние и перспективы дистанционного обучения иностранному языку в процессе подготовки будущих экономистов Национального университета пищевых технологий
}

\author{
Гаркуша Е. А.
}

\author{
Национальный университет пищевых технологий, Киев, Украина
}

\begin{abstract}
Аннотация: Статья посвящена рассмотрению текущего состояния и перспектив развития системы дистанционного обучения в Украине вообще, и в Национальном университете пищевых технологий, как одного из мощных учебно-научных комплексов государства, которое известно и за его пределами, в частности. Перечисляются ведущие государственные и иностранные ученые и педагоги, которые занимались изучением различных аспектов дистанционного обучения и внесли значительный вклад в развитие педагогической науки. Описываются результаты зарубежных встреч, наводятся аргументы по внедрению и развитию дистанционного образования в мире. Подробно характеризуются преимущества и недостатки онлайн образования, перечисляются особенности данного вида обучения. С целью лучшего понимания понятия система дистанционного образования, одним из ключевых моментов статьи, по нашему мнению, является характеристика различий дистанционной формы образования и заочной. В статье рассматривается понятие дистанционного обучения как такое по окончании которого студент получает диплом государственного образца о высшем образовании. Исследование было сужено к отдельной категории студентов, которые проходят учебно-профессиональную подготовку по специальностям экономического профиля на дистанционной основе. Одним из обязательных дисциплин в НУПТ является иностранный язык, изучение которой приобретает особое значение для будущего развития и конкурентоспособности как отдельного студента, так и государства в целом. Целями изучения дисциплины иностранный язык студентовэкономистов является развитие навыков оперирования узкоспециализированной лексикой и терминами, ведения деловой беседы и переписки с иностранными партнерами. Для достижения поставленной цели на уровне дистанционного образования, необходима разработка специальных теоретических и практических курсов которые бы давали возможность изучать дисциплину в полном объеме, овладеть и развить навыки устной и письменной деловой речи. В статье рассматривается поэтапный переход и внедрение системы дистанционного образования в НУПТ. Указываются предпосылки становления дистанционного образования и пути дальнейшего развития. Отмечается, что основным средством дистанционного образования в НУПТ является система Moodle. В статье описываются преимущества и недостатки использования данной системы, отмечаются пути ее совершенствования и модернизации. В секции «Обсуждение» для сравнения полученных результатов исследования подаются на рассмотрение отдельные достижения других высших учебных заведений Украины.
\end{abstract}

Ключевые слова: дистанционное обучение, дистанционные технологии, английский язык, профессиональная подготовка, экономисты, высшее образование. 


\section{Bcmyn}

На сьогоднішній день в світі активно відбувається процес реорганізації освіти пов'язаний з інформаційною революцією та викликами сьогодення. Кен Робінсон, міжнародний радник з питань освіти та їі модернізації, в своєму виступі на TED2010 Talks наголосив на необхідності створення належних умов для прояву природнього таланту. «Людські ресурси схожі на природні тим, що цінності закладені глибоко, що їх треба вишукувати, що на поверхні вони не лежать, що для їхнього прояву треба створювати умови. Усі без винятку системи освіти знаходяться в даний час на стадії реформування. Але цього недостатньо. Реформа вже даремна, бо вона покликана удосконалити непрацюючу модель. Нам потрібна не еволюція, а революція в освіті. Освіта повинна бути перетворена у щось нове» [3]

Відомо, що успішне працевлаштування випускників окремого вищого навчального закладу $\epsilon$ основним індикатором якості освіти в ньому. У зв'язку з розширенням міжнародних зв'язків України, її інтеграції до європейської та світової спільноти та бурхливим розвитком інформаційних технологій, підвищуються вимоги до кваліфікації кадрів на ринку праці.

Пріоритет сьогодні отримують не тільки високоінтелектуальні, цілеспрямовані, креативні особистості. До випускників сьогодення висуваються додаткові вимоги щодо вільного володіння іноземною мовою як на побутовому рівні, так і на рівні спеціаліста окремої галузі. Постає необхідність в більш поглиблених знаннях специфічної лексики, вмінні переключатися з однієї мови на іншу.

Для роботодавця наступні чинники свідчать про здатність успішно організувати діяльність у широкому соціальному, економічному, культурному контекстах як в Україні, так і за її межами, вміння налагодити зв'язки з міжнародними партнерами. Багатомовність та полікультурність вважаються необхідними для майбутніх громадян принципово нового Європейського простору, й України відповідно.

Суттєво зросли вимоги й до якості освіти. Нині більш широкого використання набувають активні форми навчання, дедалі частіше впроваджуються в навчальну діяльність сучасні інформаційні та комунікаційні технологій. Викладач поступово перестає бути основним джерелом інформації й набуває нових функцій організатора та керівника науковою роботою, коучера та експерта, мета якого навчити студента самостійно вирішувати поставлені завдання, опановувати нові знання, вести пошук необхідної інформації, скорегувати напрями пошуку.

Ще однією тенденцією у вищих навчальних закладах України є скорочення аудиторних годин та відведення більшої їх кількості на самостійну роботу. На сьогоднішній день роль самостійної роботи зросла настільки, що постає необхідність в її плануванні, створенні для ней спеціальних методів, засобів та форм навчання. Зважаючи на це, логічним $€$ неспроможність вирішити велику частину сучасних завдань, поставлених перед освітою, лише за допомогою освітніх навчальних закладів. Ця проблема потребує пошуку більш есрективних можливостей для навчання.

На сьогодні розвиток дистанційного навчання сприймається як новий рівень модернізації системи освіти держави. Широко відома з досвіду зарубіжних країн Західної Європи, США та інших розвинених країн [7;22], дистанційна форма навчання розглядається як можливість підвищити конкурентоспроможність України на ринку надання послуг в освіті.

Оминаючи даний аспект Україна ризикує залишитися без значної кількості абітурієнтів, які замість вітчизняних вищих навчальних закладів обиратимуть їх більш модернізовані аналоги закордоном, які дають можливість отримати освіту в дистанційному форматі. Як результат, це загрожуватиме зниженням конкурентоспроможності української освіти в світовому просторі.

Беручи до уваги вищезазначене, актуальним $€$ проведення досліджень щодо створення та розробки теоретичних та практичних ідей спрямованих на вирішення проблем посилення та оптимізації вивчення іноземної мови, інтенсифрікацію мовної та мовленнєвої підготовки, розробку відповідних методик навчання в Українських навчальних закладах.

Система дистанційного навчання існує в Україні досить незначний час й ще не набула великої розповсюдженості серед вищих навчальних закладів. Вона скоріше перебуває в стані становлення. Проте, маємо зазначити, що її важливість та перспективність вже має своє відображення в нормативноправовій базі [13] та науковій літературі, зокрема й такій, що присвячена саме вивченню проблем дистанційного навчання англійській мові в немовних навчальних закладах [16; 18]. За умов належного 
переймання та використання світового досвіду, поєднання прогресивних комп'ютернотелекомунікаційних технологій з найкращими методами традиційної форми навчання в перспективі дистанційна форма навчання може набути стрімкого розвитку.

Наукові дослідження українських учених Авксентьєвої О.І., Авшенюк Н.М. «Модернізація педагогічної освіти в європейському та євроатлантичному освітньому просторі», Зязюн Л.І., Лещенко М.П. «Теорія і практика використання веб-орієнтованих технологій у здоров'язбережувальному навчанні учнів початкових класів», Матвієнко О.В., Пуховської Л. П. «Проблеми інтеграції педагогічної освіти України в загальноєвропейський освітній простір» присвячені розгляду та перейманню позитивного досвіду європейських країн у галузі освіти. Окремо дистанційне навчання як форму надання освіти було розглянуто такими освітянами як Биков В., Дорошенко Ю., Дмитренко П., Корсак К., Корсунська Н., Кухаренко В., Пасічник Ю., Стефаненко П., Шуневич Б. Проблему підвищення ефективності навчання за допомогою інформаційних технологій досліджували наступні вчені: В. Биков, М. Кадемія, Ю. Жук, Р. Гуревич. Концептуальні педагогічні положення про дистанційне навчання були висвітлені в працях О. Андрєєва, Г. Козлакова, П. Стефаненка. Використання телекомунікаційних засобів в творчому навчанні підіймалися в наукових доробках Г. Андріанова, А Кудіна, А. Хуторського.

Проте досягнутий за останні роки прогрес у впровадженні інформаційних технологій та комп'ютерних засобів у процес навчання й відсутність праць про сучасний стан, проблеми та перспективи дистанційного навчання англійській мові студентів вузького профрілю, зокрема студентів економічних спеціальностей, зумовила необхідність проведення дослідження в цій галузі.

Отже, метою нашої роботи є розгляд стану та перспектив впровадження дистанційного навчання англійській мові безпосередньо в контексті професійної підготовки майбутніх економістів.

\section{II Матеріал і методи дослідження}

Відомо, що дистанційна фрорма навчання вже багато років успішно функціонує в найбільш розвинених країнах світу. $65 \%$ американських вищих навчальних закладів ввели дистанційне навчання як стратегічний хід з метою покращення сфери освітніх послуг. В Україні її введенню сприяло прийняття Закону України «Про Національну програму інфрорматизації», затвердження Постанови Кабінету Міністрів України від 23.09.2003 р. № 1494 «Програми розвитку системи дистанційного навчання на 2004-2006 рр.», Наказу міністра освіти і науки України № 802 від 04.12.2003 р. «Про затвердження Заходів щодо реалізації Програми розвитку системи дистанційного навчання на 2004-2006 рр.», затвердження Наказом Міністерства освіти і науки України Положення «Про дистанційне навчання» № 40 від 21.01.2004 р. [8; 14]. Вже зараз в нашій державі $€$ університети в яких впроваджена дистанційна освіта і навчання. Одним з них є Національний університет харчових технологій, місто Київ.

Завдяки IT-технологіям та їх введенню в навчальний процес заочне навчання модернізується й стає все більш схожим на дистанційне. Проте важливим $є$ розуміння самої сутності дистанційного навчання і його відмінності від заочної форми навчання. Заочний формат поєднує риси денної форми навчання та самостійної освіти й характеризується фазністю. Під час першої фази, а саме настановчої сесії, студенти зустрічаються з викладачами безпосередньо в стінах навчального закладу, отримують необхідні знання та літературу, план виконання завдання для здачі екзамену чи заліку з окремої дисципліни. Друга фаза - екзаменаційно-залікова сесія, перевіряється результати засвоєння матеріалу. При цьому між двома фазами зазвичай досить великий проміжок часу.

Дистанційне навчання - це прогресивна педагогічна технологія. Нині існує багато поглядів на поняття дистанційна освіта та навчання. Деякі вчені відокремлюють дану форму навчання як самостійну й абсолютизовану. Інші ж вбачають її як складову частину, сукупність методів для передачі та вивчення нового матеріалу. Головною причиною цьому було відсутність до недавнього часу єдиної концепції стосовно поняття дистанційне навчання як форми надання освітніх послуг.

Найбільш чітким на наш погляд є визначення поняттю дистанційне навчання Штихно Л. В. «дистанційне навчання - це форма навчання з використанням комп'ютерних і телекомунікаційних технологій, які забезпечують інтерактивну взаємодію викладачів та студентів на різних етапах навчання і самостійну роботу з матеріалами інформаційної мережі» [21]

В нашому дослідженні розглядається дистанційна форма навчання як така форма організації навчального процесу в вищих навчальних закладах, в результаті якої передбачається можливість 
отримання випускниками дипломів державного зразка про відповідний освітній та освітньокваліфікаційний рівень.

Особливістю дистанційної освіти є задоволення освітніх потреб громадян різної вікової категорії, забезпечення можливості отримання освітньої та професійної підготовки всіх бажаючих впродовж життя, а отже сприяє появі в суспільному житті поняття безперервності освіти. Таким чином, дистанційна форма навчання покликана вирішувати цілу низку проблем та питань, що постає перед громадянами різних країн, зокрема України: можливість підвищити рівень кваліфікації без відриву від виробництва, отримати другу вищу освіту та розширити сферу додаткової освіти, проконсультувався 3 іноземними фахівцями, обмінятися досвідом та поширити власний, при цьому не вникає потреби вирішувати питання щодо зміни місця проживання, не постає необхідність залишати сім'ю, економляться ресурси та час.

Гнучкість - головний принцип дистанційного навчання. Він полягає в інтерактивному спілкуванні між студентом та викладачем без необхідності в їх зустрічі, надає можливість навчатися у вільний час, планувати свій особистий графрік та самостійно опановувати необхідний матеріал й здобувати навички за обраною спеціальністю або курсом за допомогою використання інформаційних та комунікаційних технологій [12].

Романюк С. М. в своїй статті перелічує ще деякі характеристики дистанційної освіти: модульність (модульний принцип організації груп та курсів), паралельність (можливість здійснювати навчання паралельно з трудовою діяльністю або з отриманням іншої освіти), велика аудиторія (можливість знаходити необхідний матеріал в різних джерелах, обмінюватись набутим результатом з іншими студентами, переймати позитивний досвід), економічність (ефективне використання навчальних площ та технічних засобів), технологічність (використання новітніх технологій), соціальність (отримання освіти незалежно від місця проживання, стану здоров'я і соціального статусу), інтерактивність (можливість отримати освіту закордоном без примусового виїзду з рідної країни), якістю (завдяки ретельно підібраним матеріалам та інформаційному наповненню курсів дистанційна освіта, постійної перевірки та оновленню матеріалу дистанційна форма освіти не поступається в якості денній). [21]

Проте існує й ряд досить ґрунтовних недоліків, які можуть негативно вплинути на кожну 3 вищезазначених характеристик. Попри можливість соціалізації та спілкування без обмежень, існує певна недостатність соціальної взаємодії через те, що спілкування відбувається в віртуальному просторі. Також не винятком є й проблеми з технічним оснащенням, які в свою чергу можуть призвести до значних економічних витрат. Крім того, ряд людей досить негативно ставиться до новітніх інформаційних технологій й не володіє знаннями щодо оперування комп'ютером тощо, надаючи перевагу більш традиційним джерелам освіти.

\section{III Результати}

Вже понад 85 років Національний університет харчових технологій міста Київ, зокрема його структурний підрозділ Навчально-науковий інститут економіки і управління здійснює професійну підготовку висококваліфікованих спеціалістів економічного профілю за освітньо-кваліфікаційними рівнями бакалавр та магістр. Інститут економіки і управління орієнтований на підготовку висококонкурентних фрахівців, які володіють глибокими фаховими знаннями, мають безперервну комп'ютерну підготовку протягом всього періоду навчання та вільно володіють іноземною мовою. Студенти мають можливість обирати навчання на очній, заочній або дистанційній формі. Кожного року в зимовий період університет переходить на дистанційне навчання.

Студенти економічних спеціальностей вивчають англійську та німецьку мови на вибір. Метою викладання навчальних дисциплін Ділова іноземна мова, Іноземна мова (за професійним спрямуванням), Іноземна мова (бізнес-курс), які викладаються в НУХT, $є$ формування необхідної комунікативної компетенції у сфрерах професійного та ситуативного спілкування в усній та письмовій формах.

Основними завданнями вивчення вищезазначених дисциплін $€$ набуття навичок практичного володіння іноземною мовою в різних видах мовленнєвої діяльності в обсязі тематики, зумовленої професійними потребами; одержання новітньої фрахової інформації через іноземні джерела; користування усним монологічним та діалогічним мовленням у межах побутової, суспільно-політичної, 
фахової тематики; переклад з іноземної мови на рідну текстів фахового характеру; реферування та анотування комп'ютерної літератури рідною та іноземною мовами.

Аналізуючи посадові інструкції професійної діяльності економістів можна зробити висновок, що в більшій мірі пріоритетність надається вмінням письмового мовлення: підготовка вихідних даних для складання проектів, виконання розрахунків з необхідних матеріальних, трудових і фрінансових витрат здійснення економічного аналізу господарської діяльності підприємства та його підрозділів з подальшим занесенням їх у звіти підприємства, оформлення матеріалів для укладання договорів, тощо.

Проте, зважаючи на інтенсивність інтеграційних процесів держави, прагнення до налагодження закордонних зав'язків, все більшої актуальності набуває вміння спілкуватися англійською мовою в усній формі, адже в професійній діяльності не виключено необхідність у стажуванні та відрядженнях закордон. Дистанційне навчання дає змогу вирішити дану проблему шляхом телекомунікаційного спілкування студента та викладача, викладача і викладача для консультування та поширення досвіду, студентів між собою або навіть з носіями мови, що дає змогу скорегувати вимову та правильність наголосів в словах.

Дослідивши літературні джерела про зарубіжний досвід щодо введення та практики дистанційної освіти можемо зробити висновок, що перехід до даного освітнього формату не можу бути різким. На сьогоднішній день комбінована форма отримання освіти $€$ найбільш ефективною.

Першою передумовою введення дистанційного навчання в НУХТ було використання електронної пошти, за допомогою якої викладачі відправляли студентам завдання з роз'ясненням та необхідну літературу для його виконання, а ті, в свою чергу, надсилали виконані завдання у зворотному листі. Цей метод зв'язку студента й викладача є досить зручним, адже дозволяє уникати додаткових витрат та економить час: немає потреби роздруковувати завдання на папері, носити папери з роботи, адже викладач має змогу перевірити їх вдома, студент же в свою чергу має можливість оперативно отримати відповідь на запитання, проконсультуватися з тієї чи іншої проблеми.

Ще однією передумовою популяризації дистанційного навчання стало використання такого засобу як електронна версія навчально-методичного посібника. Студенти економічних спеціальностей мають повне методичне забезпечення, доступне в електронному вигляді на сайті бібліотеки НУХТ. Кожен зареєстрований студент НУХТ має можливість в будь-який час скористатися ресурсами бібліотеки 3 будь-якого електронного пристрою. Електроні версії навчально-методичної літератури та електронна пошта використовуються і зараз, як допоміжні методи в класичній освіті.

Проте з часом фрункція електронних версій підручників буде спеціалізуватися в зв'язку 3 розвитком дистанційної фрорми освіти. Можливим $€$ перехід від електронної версії навчальнометодичної літератури до електронного підручника що не одним і тим же поняттям. Закон України «Про освіту» дає наступне визначення: "електронний підручник (посібник) - електронне навчальне видання із систематизованим викладом навчального матеріалу, що відповідає освітній програмі, містить цифрові об'єкти різних фрорматів та забезпечує інтерактивну взаємодію" [17] Основні принципи електронних підручників: наочність, систематичність, доступність, послідовність, відповідність особистісноорієнтованому підходу [11].

Структура електронного підручника може мати різний вигляд. Головною особливістю електронного підручника і його цінність полягає в тому, що певна базова структура наявна в підручнику може добудовуватися та корегуватися, модернізуватися та ускладнюватися в залежності від програми навчання, потреб студента й вимог викладача. Тобто з позиції англійської мови тематичні розділи, а саме лексичний матеріал і тестові завдання можуть бути підлаштовані під рівень знань окремих груп. Візуальність сприйняття $€$ основною характеристикою електронного підручника. Вона стає більш динамічною, яскравішою завдяки можливості наповнення електронних підручників візуальними схемами, таблицями, картинками і навіть аудіо- та відеоматеріалом.

Основним засобом дистанційного навчання англійській мові в Національному університеті харчових технологій $є$ застосування системи Moodle. Зазначена система дозволяє викладачам створювати, редагувати, оновлювати власні електронні курси та керувати їх наповненням. Дана програма має широкий вибір щодо висвітлення навчального матеріалу: можливість викладати теоретичний матеріал, а саме тексти для читання та засвоєння нової лексики, матеріал з граматики та практичні вправи для тренування слів та граматичних правил у мові. Теоретична та практична частини 
можуть підкріплюватися відеороліками на обрані теми з інтернету та іншим супровідним матеріалом: картинками, схемами, таблицями.

Зручною є й система оцінювання знань студентів. Широкий вибір тестових форм дає можливість контролювати успішність студентів з більшості видів навчальної діяльності: читання, аудіювання, письмо.

Функція в обмеженні часу для виконання тестових завдань та для підсумкової атестації дозволяє розвивати у студентів відповідальність та дисциплінує їх.

Оцінка результатів відбувається автоматично програмою, що виключає вплив людського фактору. Студенти отримують оцінку безпосередньо після спроби, що в емоційному плані є перевагою. Викладач може відслідкувати роботу кожного студента окремо, стимулювати його на кращі результати.

Серед студентської молоді дана система сприймається позитивно, тому що вона дає можливість самостійно підлаштовувати свій графрік до вивчення поданого матеріалу. При цьому економиться й час викладачів, тому що зникає необхідність в самостійній перевірці студентських робіт.

Слід зазначити, що для модернізації даної програми необхідним $є$ безперервне осучаснення та напрацювання грунтовної теоретичної та практичної бази, створення належних навчальних курсів. Цей процес потребує кропіткої роботи і як наслідок великої кількості часу. Незважаючи на зростаючу популярність дистанційного навчання, все ж таки більшість студентів нашої держави взагалі, та студенти НУХТ зокрема, проходять професійну підготовку за очної формою освіти, проте країна впевнено крокує до змін, використовуючи різні методи дистанційної освіти в поєднанні с традиційною освітою [10].

\section{IV Обговорення}

На світовому рівні дистанційна фрорма навчання вже зараз набула значного поширення. Про це свідчить величезна кількість зарубіжних досліджень, наукових семінарів, обговорень щодо модернізації освітньої системи шляхом еволюції від традиційної до дистанційної форми, від класної дошки до електронної дошки, від паперових підручників та книжкової бібліотеки до електронних видань та онлайн ресурсів, від аудиторії слухачів до віртуальної аудиторії.

Січень 2013 року ознаменувався подією, яка відбулася в Давосі під гаслом «Онлайносвіта міняє світ». Дистанційна освіта - це тренд нового часу, який сприяє можливості отримання безперервної освіти незалежно від географічного положення, матеріального становища, національності, стану здоров'я. Під час круглого столу Дафні Коллер, один з співзасновників освітньої інтернет-платфрорми Coursera, яка є однією з найбільших у світі, підкреслила рівність в отриманні освіти для всіх людей, що є безсумнівним козирем. Мобільність навчання була відмічена як ще одна перевага дистанційної освіти.

Проте, на чолі з позитивними особливостями онлайн освіти, науковці Запорізького державного медичного університету відмічають й негативні аспекти. Пов'язані вони насамперед зі шкідливим впливом на стан здоров'я: тривала робота за комп'ютером має негативний вплив на зір, швидко стомлює студента, може призводити до нервового напруження та розладів. Крім того майже повна відсутність усного спілкування призводить до неможливості студентами чітко та образно формувати власні думки. [19]

Вітчизняні дослідники сходяться на думці, що в Україні система дистанційної освіти знаходиться на етапі становлення. Вона впроваджена лише в деяких навчальних закладах, проте більшість вузів планує введення системи дистанційної освіти найближчим часом.

На думку вчених процес переходу від традиційної до дистанційної форми навчання не може бути різким. Науковці рекомендують комбіновані варіанти запровадження дистанційного навчання коли окремі методи дистанційного навчання впроваджуються в традиційну освіту. Даний процес є логічним, через можливість звикнути до нової форми навчання не тільки студентів а й самих викладачів. За результатами усного опитування проведеного серед студентів міжнародно-правового факультету Національного юридичного університету імені Ярослава Мудрого, першим етапом впровадження дистанційного навчання може стати консультування студентів за допомогою програми Skype або електронної пошти.

Необхідною умовою належного функціонування дистанційної форми навчання в межах окремого освітнього закладу $є$ належна підготовка теоретичної та практичної бази. Дослідження електронних 
посібників та програм розміщених в Інтернеті та на CD проведене викладачами кафедри німецької та французької мов НАУ дозволяє стверджувати, що наступні матеріали не можуть стати джерелом глибоких знань й використовуватися в освітній діяльності вищих навчальних закладів. Більшість 3 них $€$ методично-непродуманими та перенасиченими аудіо- та відеоматеріалами. Тому розробка курсів для дистанційного навчання окремої дисципліни відводиться професорсько-педагогічному складу самого університету, в якому планується впровадження даної фрорми навчання. [20]

\section{V Висновки}

Проаналізувавши поточний стан введення дистанційного навчання в Україні взагалі, та в Національному університеті харчових технологій зокрема, можемо зробити висновок, що наразі дистанційна форма освіти не $є$ досконалою й перебуває на початковій стадії.

Національний університет харчових технологій впровадив систему дистанційної освіти як таку після закінчення якої студент має можливість отримання диплому державного зразка про відповідний освітній та освітньо-кваліфікаційний рівень.

Перехід до впровадження дистанційної системи освіти в НУХТ відбувався поетапно. Від електронних ресурсів та електронної пошти, які використовуються в традиційній освіти і зараз, до спеціальної платформи Moodle, яка значно полегшила процес набуття знань студентами та перевірки вивченого матеріалу викладачами. Викладачі окремо створюють навчальні курси, які можуть бути скореговані, перероблені, доповнені або замінені відповідно до нових вимог освітньої програми. Контроль вивченого матеріалу відбувається автоматично системою.

Іноземна мова є обов'язковою для вивчення дисципліною студентів економічних спеціальностей НУХТ. Студенти НУХТ дистанційної форми навчання опановують матеріал дисциплін іноземна мова за профеесійним спрямуванням, ділова іноземна мова та іноземна мова (бізнес-курс), вивчаючи теоретичний матеріал зі специфічною лексикою та виконуючи тестові завдання для самоконтролю.

Наразі існують суттєві недоліки й труднощі пов'язані з різними аспектами онлайн освіти, одним 3 яких $є$ сприйняття студентами й викладачами дистанційного навчання як фрорми отримання освіти. Проте подолання їх можливе й потребує часу. Низка переваг, пов'язаних з економією часу, фінансів, тощо, які сприяють ефективному навчанню студентів, $є$ вагомішими.

В перспективі, за умов належного переймання позитивного досвіду розвинених країн, де ця система існує досить тривалий період та дає хороші результаті, кропіткої роботи навчальнопедагогічного складу вищих освітніх закладів, належного сприйняття студентською молоддю такої форми освіти, система дистанційного навчання матиме все необхідне щоб міцно вкоренитися та навіть конкурувати з вже існуючими традиційними освітніми форматами.

\section{Бібліографрічні посилання}

[1] Busse, Vera (2014). International perspectives on motivation: Language learning and professional challenges (International perspectives on English language teaching). System, 45, 259-260. doi: https://doi.org/10.1016/j.system.2014.07.002

[2] Cherniavskyi, Bohdan (2019). Formation of foreign language competence of future economists by means of distance learning system "Moodle". Young Scientist, 1 (65), 95-97.

[3] Gnedkova, O. (2016). Distance learning technologies in formation of professional training of future English teachers. Information Technologies in Education, 29, 100-115. doi: https://doi.org/10.14308/ite000614

[4] Kruse K. The Benefits and Drawbacks of e-Learning. URL: http://www.corebiztechnology.com/ software article elearning d.htm (дата звернення 05.03.2019).

[5] Mahruf, M., Shohel C. (2012). Open and Distance Learning for Teachers' Professional Development: The English in Action (EIA) Model for the Global South. International Perspectives of Distance Learning in Higher Education, 93-108. doi: https://doi.org/10.5772/33117

[6] Schmitt, Norbert (2007).Current Perspectives on Vocabulary Teaching and Learning. International Handbook of English Language Teaching, 827-841. doi: https://doi.org/10.1007/978-0-387-46301-8_55

[7] Simpson O. Supporting Students for Success in Online and Distance Education. New York and London: Routledge, 2012. $296 \mathrm{p}$.

[8] Robinson K. Bring on the learning revolution! TED2010. URL: http://www.ted.com/talks/sir_ken_robinson_bring_on the revolution?language=ru (дата звернення 01.03.2019)

[9] Torsani, Simone (2014). The role of tool and environment design in distance language learning. Future Learning, 2 (1), 29-40. doi: https://doi.org/10.7564/13-fule14

[10] Василевич Ю. В., Каліцева О. В. Дистанційна освіта студентів-юристів: сучасний стан, проблеми, перспективи / 
Спецпроект: анализ научных исследований: V Міжнар. наук.практ. Інтернет-конф., 17-18 червня 2010 р.: тези доповідей. URL: http://www.confcontact.com/2010spec tezi/pe vasilev.php (дата звернення 01.03.2019)

[11] Вишневская Г.В. Внедрение дистанционных технологий в процесс обучения иностранному языку студентовзаочников неязыковых вузов / Известия Пензенского государственного педагогического университета имени В.Г. Белинского. 2011. № 24. С. 589-592.

[12] Гозман Л. Я., Шестопал Е. Б. Дистанционное обучение на пороге XXI века. Ростов-н/Д.: Мысль, 1999. 368 с.

[13] Дацюк В. Б. Перспективи дистанційної освіти та віртуальних університетів в Україні. URL: http://scholar.google.com/ scholar?cluster $=14888492797008898119 \&$ hl= en\&oi=scholarr http://mediacenter.uz.ua/data/daciuk.pdf 01.03.2019)

[14] Державна національна програма «Освіта: Україна XXI століття». Київ, 1994 / Законодавчі акти та нормативні документи (на допомогу керівникам закладів та установ освіти). Збірник. К., 1999. $401 \mathrm{c.}$

[15] Новомлинець О. О., Дрозд О. П. Дистанційні курси. Методичні рекомендації щодо підготовки веб-ресурсу дисциплін при організації навчального процесу за дистанційною формою. Чернігів: ЧНТУ, 2013. 32 с.

[16] Дишлева Ю. В. Роль та місце сучасних методик у вивченні англійської мови в курсі дистанційного навчання / Викладання мов у вищих навчальних закладах освіти на сучасному етапі. Міжпредметні зв'язки. Наукові дослідження. Досвід. Пошуки. 2008. Вип. 13. С. 35-41.

[17] Закон України «Про освіту» від 05.09.2017 № 2145-VIII.

[18] Олійник О. В. Інноваційні технології дистанційного навчання іноземної мови для студентів немовних ВНЗ / Лінгвістичні дослідження: зб. наук. праць ХНПУ імені Г.С. Сковороди. 2014. Вип. 38. С. 238-246.

[19] Сухомлінова І. Є., Тихоновська М. А., Тихоновський О. В., Кірсанова О. В., Єрьоміна А. К., Чугін С. В. Електроний посібник, як новітній засіб навчання / Запорізький державний медичний університет. URL: http://dspace.zsmu.edu.ual bitstream/123456789/4463/1/ \%D0\%A2\%D0\%94\%D0\%9C\%D0\%A3 \% D1\%82\%D0\%BE\%D0\%BC1_285-286.pdf (дата звернення 01.03.2019)

[20] Хоменко Л. О., Балалаєва О. Ю. Досвід розробки методів дистанційного навчання іноземних мов у НАУ / "Наукові доповіді HAY" 2005-1(1). URL: http://www.nbuv.gov.ua/e-Journals/nd/2005-1/05klomin.pdf (дата звернення 01.03.2019)

[21] Штихно Л. В. Дистанційне навчання як перспективний напрям розвитку сучасної освіти / «Молодий вчений». 2016. № 6(33). URL: http://molodyvcheny.in.ua/files/journal/2016/6/121.pdf (дата звернення 01.03.2019)

[22] Шуневич Б. І. Розвиток дистанційного навчання у вищій школі країн Європи та Північної Америки: автореф. дис. ... дра пед. наук: спец. 13.00 .01 «Загальна педагогіка та історія педагогіки». К., 2008. 36 с.

\section{References}

[1] Busse, Vera (2014). International perspectives on motivation: Language learning and professional challenges (International perspectives on English language teaching). System, 45, 259-260. doi: https://doi.org/10.1016/.system.2014.07.002

[2] Cherniavskyi, Bohdan (2019). Formation of foreign language competence of future economists by means of distance learning system "Moodle". Young Scientist, 1 (65), 95-97.

[3] Gnedkova, O. (2016). Distance learning technologies in formation of professional training of future English teachers. Information Technologies in Education, 29, 100-115. doi: https://doi.org/10.14308/ite000614

[4] Kruse K. The Benefits and Drawbacks of e-Learning. URL: http://www.corebiztechnology.com/ software article elearning d.htm (дата звернення 05.03.2019).

[5] Mahruf, M., Shohel C. (2012). Open and Distance Learning for Teachers' Professional Development: The English in Action (EIA) Model for the Global South. International Perspectives of Distance Learning in Higher Education, 93-108. doi: https://doi.org/10.5772/33117

[6] Schmitt, Norbert (2007).Current Perspectives on Vocabulary Teaching and Learning. International Handbook of English Language Teaching, 827-841. doi: https://doi.org/10.1007/978-0-387-46301-8_55

[7] Simpson O. Supporting Students for Success in Online and Distance Education. New York and London: Routledge, 2012. $296 \mathrm{p}$.

[8] Robinson K. Bring on the learning revolution! TED2010. URL: http://www.ted.com/talks/sir_ken_robinson_bring_on_the revolution?language=ru (дата звернення 01.03.2019)

[9] Torsani, Simone (2014). The role of tool and environment design in distance language learning. Future Learning, 2 (1), 29-40. doi: https://doi.org/10.7564/13-fule14

[10] Vasilevich, Yu. V. (2010). Distantsíyna osvita studentív-yuristív: suchasniy stan, problemi, perspektivi [Distance learning of students lawyers: the current situation, problems and prospects]. URL: http://www.confcontact.com/ 2010spec tezi/pe vasilev.php (accessed 01.03.2019). [in Ukrainian]

[11] Vishnevskaya, G. V. (2011). Vnedreniye distantsionnykh tekhnologiy v protsess obucheniya inostrannomu yazyku studentovzaochnikov neyazykovykh vuzov [The introduction of distance technologies in the process of learning the foreign language of part-time students of non-linguistic universities]. Izvestiya Penzenskogo gosudarstvennogo pedagogicheskogo universiteta imeni V.G. Belinskogo, № 24, 589-592. [in Russian]

[12] Gozman, L. Ya., Shestopal, Ye. B. (1999). Distantsionnoye obucheniye na poroge XXI veka [Distance learning on the threshold of the XXI century]. Mysl', Rostov-na-Donu, Russia, 368. [in Russian]

[13] Datsiuk, V. B. Perspektyvy dystantsijnoi osvity ta virtual'nykh universytetiv v Ukraini [Prospects of distance education and virtual universities in Ukraine]ю URL: http://mediacenter.uz.ua/data/daciuk.pdf (accessed 01.03.2019). [in Ukrainian]

[14] (1999). Derzhavna natsional'na prohrama «Osvita: Ukrayina XXI stolittya». [Education: Ukraine XXI Century]. Zakonodavchi 
akty ta normatyvni dokumenty (na dopomohu kerivnykam zakladiv ta ustanov osvity). Zbirnyk. Kyiv, Ukraine, 401. [in Ukrainian]

[15] Novomlynets', O. O., Drozd, O. P. (2013). Dystantsiyni kursy. Metodychni rekomendatsiyi shchodo pidhotovky veb-resursu dystsyplin pry orhanizatsiyi navchal'noho protsesu za dystantsiynoyu formoyu [Methodical recommendations for the preparation of the web resource of disciplines in the organization of the educational process in the form of a distance learning. CHNTU, Chernihiv, Ukraine, 32. [in Ukrainian]

[16] Dyshleva, Yu. V. (2008). Rol' ta mistse suchasnykh metodyk u vyvchenni anhlijs'koi movy v kursi dystantsijnoho navchannia [Role of modern techniques in the study of English in distance learning course]. Vykladannia mov u vyschykh navchal'nykh zakladakh osvity na suchasnomu etapi. Mizhpredmetni zv'iazky. Naukovi doslidzhennia. Dosvid. Poshuky [language Teaching in higher educational establishments of education at the present stage. Interdisciplinary connections. Scientific researches. Experience. Search], 13, 35-41. [in Ukrainian]

[17] Law of Ukraine "On Education" dated September 5, 2017 No. 2145-VIII. [in Ukrainian]

[18] Olijnyk, O. V. (2014). Innovatsijni tekhnolohii dystantsijnoho navchannia inozemnoi movy dlia studentiv nemovnykh VNZ [Innovative technologies in distance learning foreign language for students of non-linguistic higher schools]. Linhvistychni doslidzhennia: zbirnyk nauk. prats' KhNPU imeni H.S. Skovorody [Linguistic studies: Collection of Sciences. papers of KNPU named after G.S. Skovoroda], 38, 238-246. [in Ukrainian]

[19] I. Sukhomlinova, Ye., Tihonovska, M. A., Tihonovskiy, O. V., Kirsanova, E. V., Yeryomina, A. K., Chugin, S. V. (2016). Electronic manuals as a new instructional medium. Zaporizhzhya State Medical University. URL: http://dspace.zsmu.edu.ual bitstream/123456789/4463/1/ \%D0\%A2\%D0\%94\%D0\%9C\%D0\%A3_ \%D1\%82\%D0\%BE\% D0\%BC1_285-286.pdf (accessed 01.03.2019). [in Ukrainian]

[20] Khomenko, L. O., Balalayeva O. Yu. Experience of elaboration of foreign languages distance educational methods in NAU. "Naukovi dopovidi NAU" 2005-1(1). URL: http://www.nbuv.gov.ua/e-Journals/nd/2005-1/05klomin.pdf [in Ukrainian]

[21] Shtykhno L.V. (2016). Distance learning as a promising direction of developing modern education. «Young Scientist», 6 (33), 489-493. URL: http://molodyvcheny.in.ua/files/journal/2016/6/121.pdf (accessed 01.03.2019). [in Ukrainian]

[22] Shunevych, B.I. (2008). Rozvytok dystantsijnoho navchannia u vyschij shkoli krain Yevropy ta Pivnichnoi Ameryky. Avtoref. dys. dokt. ped. nauk [The Development of distance learning in higher education of the countries of Europe and North America. Abstract of Dr. ped. sci. diss.], Kyiv, Ukraine, 36. [in Ukrainian]

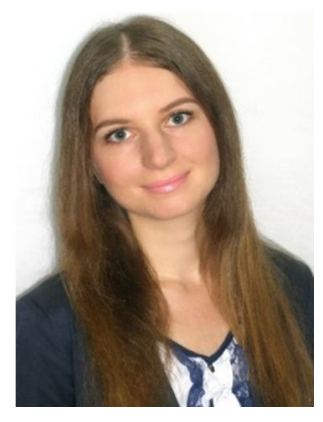

\section{Гаркуша Олена Олександрівна.}

Викладач кафедри ділової іноземної мови та міжнародної комунікації,

Національний університет харчових технологій, вул. Володимирська, 68, м. Київ, Україна, 01601.

Тел. 0953124374. E-mail: elena.garkusha1990@gmail.com

\section{Harkusha Olena Oleksandrivna.}

Teacher of Department of Business Foreign Language and International Communication,

National University of Food Technologies, Volodymyrska str. 68, Kyiv, Ukraine, 01601.

Tel. 0953124374 . E-mail: elena.garkusha1990@gmail.com

ORCID: https://orcid.org/0000-0003-2264-2517

\section{Citation (APA):}

Harkusha, O. (2019). Implementation of heuristic learning technologies for theoretic concepts formation by students mastering agricultural professions. Engineering and Educational Technologies, 7 (1), 46-55. doi: https://doi.org/10.30929/2307-

9770.2019.07.01.05

\section{Цитування (ДСТУ 8302:2015):}

Гаркуша О. О. Стан та перспективи дистанційного навчання іноземній мові в процесі підготовки майбутніх економістів Національного університету харчових технологій / Інженерні та освітні технології. 2019. Т. 7. № 1. С. 46-55. doi: https://doi.org/10.30929/2307-9770.2019.07.01.05

Обсяг статmі: $\quad$ сторінок-10 ; умовних друк. аркушів - 1,149 